UDC 811.111.378.147

DOI https://doi.org/10.32841/2409-1154.2019.42.3.31 Head of the Department of Social Sciences of the Cherkasy Faculty of the National University "Odessa Academy of Law"

\title{
THE ROLE OF FORMULAIC COMPETENCE IN DEVELOPING FOREIGN LANGUAGE COMMUNICATIVE COMPETENCE
}

\begin{abstract}
Summary. This study briefly presents the concept of competence as a general term and gives a short overview of its origin as well as main characteristics. The specific attention in the article has been given to the problem of communicative competence as one of the most controversial terms in general and applied linguistics. Our research findings have enabled us to identify the major components of communicative competence and to describe distinguishing features between linguistic and communicative competence. In this paper, we join the opinion of a number of scholars that communicative competence has become one of the most important needs that directly affect the professional activities of future specialists. This scientific research is aimed at outlining the notion of formulaic language and clarifying the role of formulaic competence understanding it as the learner's ability to produce and comprehend the utterer's intentions. The present paper analyses formulaic competence as a component of a non-linguistic communicative competence. According to our observations formulaic competence is characterized by the ability to use a language intentionally that includes knowledge of stylistic variations of formulaic expressions which can be used purposely in language production and comprehension. We have placed particular emphasis on the expediency of using competence of communication in teaching a foreign language. In context of this study we support the view that foreign language communicative competence as a certain level of language proficiency, speech and socialcultural set of knowledge, skills and abilities creates the basis for the qualified information and creative activities in various fields. The development of foreign language communicative competence is considered to be one of the main goals of foreign language learning.
\end{abstract}

Key words: linguistic competence, communicative competence, formulaic language, formulaic competence, foreign language communicative competence.

Statement of the problem. Nowadays, in the era of continuous improvement and changes there is an increased demand for specialists mastering foreign languages. Integration into the world of cultural, educational and economic space requires qualitative training professionals capable of working successfully in the global social community. Along with the acceleration of globalization processes and the development of international business ties in Ukraine, the need for perfect knowledge of a foreign language is growing in order to communicate effectively and perform the necessary functions in a certain area of professional activity [16]. Boosting economic growth in our country necessitates establishing new international contacts and wide exchange of specialists mastering foreign language. The current socio-cultural and economic situation in our country requires strengthening the role of competences in the field of vocational education. Mastering competences has become an important task not only for the young professionals, but also for those who need to raise their professional level in the process of retraining and advanced training.

The aim of the article is to analyse distinct approaches to defining communicative competence and its major components. The particular task of this paper is to examine the notion of formulaic competence and outline its main characteristics as non-linguistic component of communicative competence (hereinafter- CC).

Background to the research problem. The research problem of linguistic and communicative competence has been an object of many scientific papers: N. Chomsky, D. H. Hymes, M. Canale and M. Swain, L. F. Bachman and A. S. Palmer, R. Campbell and R. Wales, S. J. Savignon, A. M. Shakhnarovich, H. Stern, D. S. Taylor, H. G. Widdowson and others.

Many other linguists have made their contribution to the further development of communicative competence components, formulaic language and competence as well as communicative language teaching: K. Brandl, D. H. Brown, M. Celce-Murcia, Z. Dornyei, N. C. Ellis, B. Erman, M. Johnson, J. Richards, N. Schmitt, A. Wray and M. R. Perkins, A. A. Zalevskaya and others.

Discussion. Over the past decades, discovering the problem of communication in general, and vocational and pedagogical communication in particular has intensified. Scientific interest in this issue is well grounded, since the problem of communication in the conditions of globalization of society has been among the most important ones [17, p. 15]. The researchers still have a lot of unresolved issues regarding the criteria for selecting key competences, their theoretical justification and evaluation, as well as determining the essence and components of $\mathrm{CC}$ in their structure. Meanwhile, western scholars mostly interpret this category in a broad sense and understand it as the ability to interact with people, achieve their own communicative goals, and choose the type of communicative behaviour in the process of interpersonal communication. They associate communicative competence mainly with knowledge of foreign languages, which is usually a prerequisite for effective intercultural communication.

It is generally accepted that the term "competence" was introduced in the United States in 1965 by the American linguist N. Chomsky [8] in the context of the theory of language learning. Meanwhile, D. Hymes introduced to scientific circulation 
and justified the term "communicative competence" [11]. In the article "On Communicative Competence" the author expands the meaning of the concept of competence to communication, contrasting this term to "linguistic competence" applied by N. Chomsky, and sharing the opinion that a person with only linguistic competence will not be able to communicate, since only grammatical structures will be generated [11]. D. Hymes proposed his more complex and multidimensional definition of communicative competence consisting of both linguistic competence (knowledge of the grammatical structure of the language) and contextual or sociolinguistic competences (knowledge of the rules of language use in different contexts). In his definition CC is not only "as an inherent grammatical competence but also as the ability to use grammatical competence in a variety of communicative situations, thus bringing the sociolinguistic perspective into Chomsky's linguistic view of competence" [3, p. 95].

Linguistic studies recognize the term "communicative competence" offered by D. Hymes as that "is comprised of two words, the combination of which means "competence to communicate". This simple lexico-semantical analysis uncovers the fact that the central word in the syntagm "communicative competence" is the word "competence" [14, p. 94]. There is an opinion that "It is the notion of communicative competence proposed by Hymes, not the idea of (linguistic) competence offered by Chomsky, that is, the basis for the "exclusively methodological" communicative competence. Communicative competence is much wider than that of (linguistic) competence (the ability to understand and produce an unlimited number of linguistically correct sentences using the mastered language signs and the rules of their connection) [1, p. 173]. Having reviewed the theoretical studies relating to the linguistic capability (competence) and the communicative competence, O.K. Ansimova claims that these two phenomena are interrelated but not mutual replaceable [1, p. 174].

Competence is a property of an individual based on possessing a competence. A communicative competence, as a linguistically, psychologically, and methodologically organized system, is viewed as an interdisciplinary phenomenon [4]. The idea of distinction between these concepts (competence and communicative competence) in its modern guise has appeared with Chomsky's competence - performance dichotomy. It should be mentioned in this respect that "linguistic competence relates to language and linguistic performance refers to speech" $[15$, p. 90]. In current researches it is pointed out that "for Chomsky (1965), linguistic competence accounts for the implicit knowledge of grammar an ideal speaker and listener has in a homogenous speech community (ideal speakerlistener), whereas linguistic performance refers to the current use of that grammar knowledge in specific situations" [15, p. 90].

The concept of communicative competence continued to be developed by M. Canale, M. Swain [6] and D. H. Brown [5]. Their $\mathrm{CC}$ model includes four components:

- Grammatical competence is concerned with mastery of the linguistic code (verbal or non-verbal) which includes vocabulary knowledge as well as knowledge of morphological, syntactic, semantic, phonetic and orthographic rules [3, p. 97].

- Sociolinguistic competence refers to possession of knowledge and skills for appropriate language use in a social context. [3, p. 99].

- Discourse competence which accounts for the ability to connect sentences to build a coherent discourse into a meaningful whole $[15$, p. 90]. While grammatical competence focuses on sentence-level grammar, discourse competence is concerned with intersentential relationships [5, p.196].

- Strategic competence is composed of knowledge of verbal and non-verbal communication strategies that are recalled to compensate for breakdowns in communication due to insufficient competence in one or more components of communicative competence [3 p. 98].

"In the mid-nineties Celce-Murcia et al. (1995) proposed that actional competence (the ability to comprehend and produce all significant speech acts and speech act sets) should also be part of communicative competence" [7, p. 42]. However, according to M. Celce-Murcia "For most discussions of language pedagogy, the model proposed by Canale and Swain (1980), along with the elaborations proposed by Canale (1983), remain the key sources for discussions of communicative competence and related applications in applied linguistics and language pedagogy" [7, p. 41].

In the last few decades, there has been an increased interest among linguists in the study of the phenomenon of the formulaic language. R. Weinert determines formulaic language as "multi-word or multi-form strings which are produced or recalled as a whole chunk, much like an individual lexical item, rather than being generated from individual lexical items / forms with linguistic rules" [18]. N. Chomsky considered formulaic phrases as a temporary tool for beginners to learn the language, but the modern approach to formulaic language characterizes the use of formulaic sequences as a reflection of linguistic competence. We fully support the view that "The use of speech formulas not only increases the rate of speech, but also helps students to quickly absorb and process more information without the need for analytical decoding" [12, p. 98].

Research activity around formulaic language has increased considerably in the past decade. A. Wray claims that "here has long been an interest in formulaic language across a number of different domains of enquiry, including psycholinguistics, discourse analysis, phrase-ology, historical linguistics, corpus linguistics, grammar, first language (L1) acquisition, second language (L2) acquisition, clinical linguistics, computational linguistics, and others" $[19$, p. 321]. But still, "there is no consensus over a satisfactory definition of formulaic language. However, scholars tend to put a scope on the notion of formulaicity as prefabricated chunks of language that are acquired, memorised, and then retrieved whole from memory at the time of use" [19].

The acquisition of the notion of formulaicity provides a great deal of help for English as Foreign Language learners to achieve nativelike language proficiency [2]. Outlining the core characteristics of Communicative Language Teaching (CLT) Z. Dörnyei has termed the notion of "Principled Communicative Approach" (PCA) $[9$, p. 161] which "should include the teaching of formulaic language as a featured component. There should be sufficient awareness raising of the significance and pervasiveness of formulaic language in real-life communication, and selected phrases should he practised and recycled intensively" [9, p. 169]. It is vital to remember that the formulaic language competence is directly linked to fluent and automatized language production.

Formulaic competence has grown in importance; it is now acknowledged that fluent speakers of a language draw on formulaic knowledge of the target language as often as they use systematic linguistic knowledge [7, p. 48]. According to Celce-Murcia (2007), linguistic competence and formulaic competence are different 
entities. Formulaic competence is recognizes as the counterbalance to linguistic competence. Formulaic competence refers to those fixed and prefabricated chunks of language that speakers use heavily in everyday interactions [7, p. 47]. For Celce-Murcia, formulaic competence referring to recurrent fixed chunks / expressions used by native speakers to communicate with the others consists of conversational formulas, pause fillers, collocations, idioms, conversation phrases, lexical bundles, proverbs, expletives and routines.

"Acquiring a native-like formulaic competence is difficult for L2 learners as their findings demonstrate that learners' produced language is rife with underuse, overuse, and misuse of some formulaic phrases" [13]. Many studies have already demonstrated that many foreign language learners even at high levels of language proficiency experience difficulty in formulaic language acquisition and use [13, p. 198]. Modern researches support the growing consensus that formulaic language acquisition is the most difficult aspect of learning a second / foreign language [13, p. 205].

Native speakers tend to use particular formulaic expressions frequently therefore to sound like native, nonnative speakers have to use those formulaic expressions. Current studies describe five types of formulaic expressions: collocations, idioms, lexical bundles, binomial expressions, and inserts. Formulaic expressions relate closely to linguistic competence and sociocultural competence. Linguistic competence is very important to be achieved for example phonology, lexis, morphology, and syntax but it would be unbalanced without formulaic competence [14 p. 40]. We join here the opinion that "if the students use a lot of formulaic expressions, their interactions will sound more natural and frequent. Students have to be introduced to formulaic expressions especially the larger lexical units to improve their speaking [14, p. 40].

It is undoubtedly that in the modern methodological literature the components ofCC may be defined differently. There is an opinion that "Identification of such components of the communicative competence as linguistic, sociocultural, and pragmatic competences seems to be the optimal solution" [1, p. 173]. It seems worth mentioning here that "the concept of a communicative competence was further developed in the framework of the studies conducted by the European Council aimed at determining the level of language proficiency" [1, p. 171]. Undeniably, the modern requirements for the foreign language proficiency of learners imply the presence of foreign language communicative competence of future specialists. Foreign language teaching / learning remains now at a low level, and the majority of graduates turn out to be unprepared for communicative foreign language activities under the real conditions of intercultural communication.

Today the main task of learning the foreign language is the training of professional-oriented communication, and the process of learning should be practical-oriented. In this respect, we share the opinion that "foreign language communicative competence as a certain level of language proficiency, speech and social-cultural set of knowledge, skills and abilities that enable to vary acceptably and appropriately their communicative behavior in a communicative way depending on the functional predictors of foreign language communication creates the basis for the qualified information and creative activities in various fields" [10, p. 36].

To our deep conviction, foreign language communicative competence is the main goal of teaching foreign languages, that is, the ability and real readiness of learners to communicate in other languages and reach the level necessary for practical use in future professional activities. The analysis of scientific publications allowed identifying three main aspects of examining the problem of finding and introducing new technologies to form foreign language communicative competence among students of nonphilological training profiles:

- the study of the needs of the educational system in updating the curricula and programs in a foreign language;

- experimental evidence of the effectiveness of the technologies used;

- the study of the attitudes of students and teachers to the technologies used.

Conclusions. Thus, the above-mentioned information has allowed us to analyse the communicative competence considered in our research in the framework of a competence-based approach as a subject of research study or a concept for the situation expected to be achieved by everyone who learns a second or foreign language. Communicative competence reflects the ability and real readiness of learners to communicate in other languages and reach the level necessary for practical use in future professional activities. This paper offers a small glimpse of the formulaic competence that refers to the learner's ability to produce and comprehend the utterer's intentions and enables the learner of foreign language to choose the right expression in a given communicative setting. Current language policy and problems of mastering a foreign language as a means of intercultural communication require modern approaches to teaching foreign language and effective learning technologies to expanding foreign language professional communicative competence.

\section{References:}

1. Ansimova O.K. Competence-Based Approach to Interpretation of a Language Sign by an Individual: The Search for a Term. The Online ISSN of Advances in Social Science, Education and Humanities. Research University of Northern Iowa, Cedar Falls, United States. Vol. 333, 2019. P. 170-174.

2. Assassi T., Benyelles R. Formulaic Language for Improving Communicative. Arab World English Journal (AWEJ) Vol.7. No.1, March, 2016. P. 163-176.

3. Bagarić V., Djigunović J. M. Defining Communicative Competence. Metodika. Vol. 8, br. 1, 2007. P. 94-103.

4. Bastrikova E. M. Kommunikativnaya Kompetencziya kak Lingvodidakticheskij Fenomen. Russkaya $i$ Sopostavitelnaya Filologiya: Lingvokulturologicheskij Aspekt / Kazan. gos. un-t. Kazan, 2004. S. 43-48. URL: http://old.kpfu.ru/f10/bibl/resource/articles. php?id=6\&num $=11000000$.

5. Brown D. H. Principles of language learning and teaching (5thed.) New York: Pearson Education, 2006. 347 p. URL: http://angol.uni-miskolc.hu/ wp-content/media /2016/10/Principles_of_language_learning.pdf.

6. Canale M., Swain M. Theoretical Bases of Communicative Approaches to Second Language Teaching and Testing. Applied Linguistics, 1980. Vol. 1. P. 1-47.

7. Celce-Murcia M. Rethinking the Role of Communicative Competence in Language Testing. In E. A. Soler and M. P. S. Jordà (Eds.). Intercultural Language Use and Language Learning. Dordrecht, the Netherlands: Springer, 2007. P. 41-57.

8. Chomsky N. Aspects of the Theory of Syntax. Cambridge, Massachusetts : The M.I.T. Press, 1965. 261 p.

9. Dörnyei Z. Communicative Language Teaching in the Twenty-First Century: The 'Principled Communicative Approach'. In J. Arnold 
\& T. Murphey (Eds.), Meaningful Action: Earl Stevick's Influence on Language Teaching. Cambridge : Cambridge University Press, 2013. P. 161-171.

10. Fahrutdinova R.A., Yarmakeev I.E., Fakhrutdinov R.R. The Formation of Students' Foreign Language Communicative Competence during the Learning Process of the English Language through Interactive Learning Technologies (The Study on the Basis of Kazan Federal University). English Language Teaching, 2014. Vol. 7, No. 12. P. 36-46.

11. Hymes D. H. On Communicative Competence. J. B. Pride and J. Holmes (eds) Sociolinguistics. Selected Readings. Harmondsworth: Penguin, 1972. P. 269-293.

12. Korolenko I., Loksha O. Rechevye Formuly kak Sredstvo Preodoleniya Yazykovogo Barera pri Izuchenii Inostrannogo Yazyka. Sovremennye Issledovaniya Soczialnykh Problem. T. 8. o 6-2, 2017. S. 92-101.

13. Mohammadi M., Es-hagi S. Examining EFL Learners' Formulaic Competence and Factors Affecting Formulaic Sequences' Learnability. International Journal of English Language \& Translation Studies. 6(2). 2018. P. 195-208.

14. Neno H., Agustien H. I. R. The Use of Formulaic Expressions in EFL Students' Interactions. English Education Journal, 6(1). 2016. P. 39-44.

15. Obeso W.S. Exploring Communicative Competence Development in an EFLT Classroom at Cursos Libres. Zona Próxima, núm. 23, 2015, P. 88-103. URL: http://scielo.org.co/scielo.php?script=sci_ arttext\&pid=S2145-94442015000 200007.

16. Potenko L.O. Inshomovna Komunikativna Kompetentnist u Proczesi Formuvannya Profesijnoyi Kompetencziyi Majbutnikh Fakhivcziv Bankivskoyi Spravi. Naukovi Zapiski Naczional nogo Universitetu "Ostrozka akademiya». Seriya «Filologichna»: Zbirnik Naukovikh Pracz. Ostrog, 2014. Vip. 42. S. 285-287.

17. Skvortsova S. O., Vtornikova Yu. S. Profesiino-Komunikatyvna Kompetentnist Uchytelia Pochatkovykh Klasiv: Monohrafiia. Odesa : Abrykos Kompany, 2013. 290 s.

18. Weinert R. The Role of Formulaic Language in Second Language Acquisition: A Review Applied Linguistics. 16(2). 1995. P. 180-205.

19. Wray A. Formulaic Language: Pushing the boundaries. Oxford, UK : Oxford University Pres, 2008. 305 p.
Потенко Л. Роль формульної компетентності в розвитку іншомовної комунікативної компетентності

Анотація. Це дослідження стисло представляє термін «компетентність» як загальне поняття та надає короткий огляд його походження, а також його основних характеристик. Особлива увага у статті приділяється проблемі комунікативної компетентності як одного з найбільш суперечливих термінів загальної та прикладної лінгвістики. Результати наших пошуків дозволили нам виявити основні компоненти комунікативної компетентності та описати відмінності між лінгвістичною та комунікативною компетентністю. У цій роботі ми поділяємо думку низки науковців, що комунікативна компетентність стала однією з найважливіших потреб, що безпосередньо впливають на професійну діяльність майбутніх фахівців. Це наукове дослідження спрямоване на визначення поняття формульної мови та уточнення ролі формульної компетентності, розуміючи ії як здатність того, хто навчається, продукувати і осмислювати наміри мовця. У цій роботі проаналізовано формульну компетентність як складову частину нелінгвістичної комунікативної компетентності. Згідно 3 нашими спостереженнями формульна компетентність характеризується здатністю спеціально використовувати мову, що включає знання стилістичних варіацій формульних виразів, які можуть бути цілеспрямовано використані в мовному продукуванні та розумінні. Ми зосередили особливу увагу на доцільності використання компетентності спілкування в іншомовному навчанні. У контексті цього дослідження ми поділяємо думку про те, що іншомовна комунікативна компетентність як певний рівень володіння мовою, мовленням та соціально-культурним набором знань, умінь та навичок створює основу для кваліфікованої інформаційно-творчої діяльності в різних галузях. Розвиток іншомовної комунікативної компетентності вважається однією 3 головних цілей вивчення іноземної мови.

Ключові слова: лінгвістична компетентність, комунікативна компетентність, формульна мова, формульна компетентність, іншомовна комунікативна компетентність. 